\title{
Adverse Selection and the Opaqueness OF INSURERS
}

\author{
Tao Zhang
}

Larry A. Cox

Robert A. Van Ness

\begin{abstract}
While adverse selection problems between insureds and insurers are well known to insurance researchers, few explore adverse selection in the insurance industry from a capital markets perspective. This study examines adverse selection in the quoted prices of insurers' common stocks with a particular focus on the opacity of both asset portfolios and underwriting liabilities. We find that more opaque underwriting lines result in greater adverse selection costs for property-casualty $(\mathrm{P}-\mathrm{C})$ insurers. A similar effect is not apparent for life-health (L-H) insurers and we find no effect of asset opaqueness on adverse selection for either L-H or P-C insurers.
\end{abstract}

\section{INTRODUCTION}

Insurance researchers are familiar with adverse selection from the perspective of insurer-policyholder transactions. In this study, we explore a different type of adverse selection. We examine adverse selection in the secondary security market prices of insurer stocks. We particularly focus on the effects of both asset and liability opacity on this form of adverse selection.

If information regarding a company is transparent, costless, and simultaneously received by all secondary market traders, then there will be no adverse selection costs in capital markets. However, if a company is hard to evaluate by outside traders and some traders can value the firm more accurately because of either private information or superior information-processing abilities, then the adverse selection component of the quoted spread (ask price minus bid price) for a company will reflect these informational differences.

Tao Zhang works for Ernst and Young, and Larry Cox is a professor and Robert Van Ness is an associate professor at the University of Mississippi, School of Business, Holman Hall, University, MS 38677. Cox and Van Ness can be contacted via e-mail: lcox@bus.olemiss.edu and rvanness@bus.olemiss.edu, respectively. We would like to thank Michael McShane, Van Nguyen, Andriy Shkilko, Bonnie Van Ness, and seminar participants at the University of Mississippi for comments on earlier versions of this article. 
Researchers analyze the impact of a variety of information factors, including information opaqueness, on the adverse selection component of the spread. For instance, the relative opaqueness of different assets has been shown to affect the adverse selection costs impounded in bank stocks (Flannery, Kwan, and Nimalendran, 2004).

Little work concerning adverse selection in the secondary market for insurer equities has been undertaken. This is notable because Ross (1989) argued that insurance companies and thrift organizations have the most severe information asymmetry between the firm and its claimholders with respect to the firm's asset portfolio. For instance, a policyholder usually has little information about the specific investment of premiums paid to the insurer and, similarly, a depositor probably knows little about specific loans made by the bank with his deposited funds.

Although some sources of information opaqueness for banks and insurers are common, others are unique to insurers. For instance, adverse selection generated by informational asymmetries specific to liabilities is particularly relevant to insurers. When compared to banks' liabilities, which generally have well-defined durations and amounts, insurers' liabilities generate greater asymmetric information because of the less certain duration of claim payments and the difficulty of predicting ultimate loss amounts. Babbel and Merrill (2005) note that the complexity and opaqueness of insurance contracts allow managers of both property-casualty $(\mathrm{P}-\mathrm{C})$ and life-health $(\mathrm{L}-\mathrm{H})$ insurers to create illusory values. Among the practices they observe for selected L-H insurers are deliberately simplistic discounting of reserves, illegitimate surplus relief reinsurance, and commission financing schemes, all of which promote understated reserve liabilities and overstated surplus. Colquitt, Hoyt, and McCullough (2006) explain how managers of property-liability insurers are able to use greater discretion in setting loss reserves, which results in information asymmetry in investment markets. Polonchek and Miller (1996) provide empirical evidence regarding greater information asymmetries with respect to the assets and liabilities of insurers compared to banks.

In this study, we empirically evaluate the relation between the adverse selection impounded in insurer stock prices and firm-specific characteristics such as information opacity and the trading characteristics of an insurer's equity. We use a sample of L-H and P-C insurers traded on the New York Stock Exchange (NYSE) from 1996 through 2004. We specifically explore the effects of asset and liability opacity on the adverse selection component of bid-ask spreads, controlling for financial factors, the activity of informed traders, and other trading characteristics.

Our empirical results show that the adverse selection costs of insurance stocks are positively related to underwriting line opacity and trading volume volatility. These costs also are negatively related to price and trading volume. Our results support the hypotheses that liability opacity, volume volatility, and, possibly, stock price volatility lead to greater information asymmetry and, therefore, adverse selection in insurer equities traded on the NYSE.

The rest of the article is organized as follows. In the next section, we review the theoretical background of information asymmetry and adverse selection in the capital markets and empirical modeling. We then describe our data and method in the 
following section. Empirical results are presented subsequently and our conclusions are stated in the final section.

\section{Adverse Selection in Capital Markets}

While a substantial research stream exists on information asymmetry and adverse selection between insurers and policyholders (e.g., Dionne and Doherty, 1992), information asymmetry between managers and outside investors can generate another form of adverse selection problem. Specifically, "good" firms (i.e., firms with bright prospects that generate growth) tend to raise easy money from overvaluation (Myers and Majluf, 1984). This form of adverse selection occurs because managers possess private information. Ross (1989) specifically argues that when managers of insurance companies and banks have informational advantages over other claimants about their firms' operations, the costs of monitoring, bonding, and control are higher for these financial institutions. In contrast, shareholders of mutual funds can easily get complete information about the operations, especially asset portfolio activities, of these financial firms. Ross therefore concludes that insurance companies and banks are more opaque than mutual funds and the resulting adverse selection favors managers.

Ordinarily, outside claimants have little access to private information held by managers of insurers and banking or thrift institutions. Several empirical studies document evidence of information asymmetry impounded in the asset portfolios of such financial institutions. For instance, Polonchek and Miller (1999) find significant and negative abnormal returns for equity offerings by insurers, and conclude that the information asymmetry with respect to the asset portfolios of insurers increases the market expectation of adverse selection favoring managers. Slovin, Sushka, and Polonchek (1992) find significant and negative effects of bank equity issuance on rival banks' stock prices, and attribute this contagion effect to information asymmetry with regard to bank asset portfolios. Fenn and Cole (1994) examine asset-write-down announcements by insurers and find similar contagion effects.

\section{Adverse Selection and the Market Microstructure Literature}

Market microstructure research offers a view of adverse selection that is specific to the secondary capital markets. Bagehot (1971) introduces information asymmetry when the market maker possesses only public information, but some investors have private information. To the extent that the market maker cannot distinguish between informed and uninformed traders, the losses to informed traders must be offset by the profits from uninformed traders. Based on a straddle option model, Copeland and Galai (1983) indicate that market makers use spreads to maximize profits by balancing losses to informed traders and profits to uninformed traders. Kyle (1985) formalizes Bagehot's argument by developing a model showing that informed traders make profits at the expense of noise (uninformed) traders.

\section{Effects of Asset and Business Opaqueness on Adverse Selection Components}

The trading of stocks in the secondary market can convey information when some traders possess superior information about the true value of the stock. As a consequence, the market maker will adjust the spread to protect himself from informed traders. The source of information opaqueness and the existence of informed traders 
are two important determinants of the adverse selection component in bid-ask spreads.

Flannery, Kwan, and Nimalendran (2004) (FKN) examine the relation between adverse selection costs and the asset composition of banks, and find that bank asset categories differ in information opacity. FKN's results show that bank loans generally are opaque. Because no active secondary market exists for most bank loans, outside investors encounter difficulties in assessing the fair market value of bank loans. In contrast, bank managers have valuable private information about borrowers' financial conditions through monitoring and screening, so bank managers can value loans more accurately than outside investors (Campbell and Kracaw, 1980; Berlin and Loeys, 1988; Diamond, 1989, 1991). Hence, most adverse selection costs of banking institutions come from information asymmetry with respect to bank assets, particularly bank loans.

In contrast to banks, insurers encounter information asymmetry in both assets and liabilities. Morgan (2002) provides evidence, based upon disagreements among rating agencies, that insurers can be even more opaque than banks. While his focus is on assets, Morgan cannot identify whether greater insurer opacity derives from assets, liabilities, or both.

Table 1 provides classifications of assets and liabilities reflecting different lines of business (LOB). On the asset side, insurance companies invest their assets not only in easily valued liquid assets, such as cash or cash equivalents, stocks, and bonds, but also in relatively opaque assets, such as mortgage and private placement loans and bonds. Mortgages and "private placements" should be comparably opaque to the loans made by banks.

Compared to banks' liabilities that have relatively predictable durations because of the nature of fixed-rate obligations, insurers' liabilities are harder to evaluate for a number of reasons. ${ }^{1}$ The obligations of property-liability insurers are subject to shocks because of natural catastrophes, limited actuarial data in newer lines such as environmental liability and terrorism insurance, and the uncertainty of losses from longer tailed lines such as general liability and workers compensation (see, e.g., Cummins, Phillips, and Smith, 2001 for further discussion). As noted previously, Babbel and Merrill (2005) detail how the complexity and opaqueness of L-H contracts can allow insurance managers to take advantage of their less-informed customers via a variety of practices that allow the manipulation of liability and surplus values. Other researchers argue that health insurance contracts are even more complex than life insurance and annuity contracts because benefits are relational, especially considering uncertainties inherent in health care laws, innovations in medical technology, and relations with third-party health care providers (Baranoff and Sager, 2002; Hendel and Lizzeri, 2003).

Based upon research in the finance and insurance literature, we deduce that insurance stocks present an exceptionally good opportunity to determine how different forms of information asymmetry and adverse selection are interrelated, as well as how stock prices are affected by the information arrayed across different asset compositions and

\footnotetext{
${ }^{1}$ Bank liabilities are mainly composed of fixed-rate CDs and other savings instruments for which future commitments are highly predictable.
} 


\section{TABLE 1}

Classification of Asset and Liability Compositions for Different Types of Insurers

Panel A: Asset and Liability Categories of Life-Health Insurers

\begin{tabular}{lc}
\hline \multicolumn{2}{c}{ Balance Sheet of Life-Health Insurers } \\
\hline Asset & \multicolumn{1}{c}{ Liability } \\
\hline $\begin{array}{l}\text { Transparent assets (cash, cash equivalents, } \\
\text { marketable securities, and market value } \\
\text { of separate account) }\end{array}$ & $\begin{array}{c}\text { Transparent lines (ordinary life, credit life, } \\
\text { group life, industrial life, credit accident } \\
\text { \& health, other accident \& health, } \\
\text { ordinary individual annuity, and group } \\
\text { annuity) } \\
\text { Opaque lines (group accident and health) }\end{array}$ \\
$\begin{array}{l}\text { Opaque assets (mortgage loans, real estate } \\
\text { investment, private placement loans and } \\
\text { bonds, premium notes, premiums } \\
\text { receivable, other investments, and } \\
\text { reinsurance ceded) }\end{array}$ &
\end{tabular}

\begin{tabular}{ll}
\hline \begin{tabular}{l} 
Panel B: Asset and Liability Categories of Property-Casualty Insurers \\
\hline \multicolumn{1}{c}{ Balance Sheet of Property-Casualty Insurers }
\end{tabular} \\
\hline $\begin{array}{l}\text { Asset } \\
\begin{array}{l}\text { Transparent assets (cash, cash equivalents, } \\
\text { marketable securities and market value of } \\
\text { separate account) }\end{array}\end{array}$ & $\begin{array}{c}\text { Transparent lines (fire, allied lines, } \\
\text { earthquake, group accident \& health, } \\
\text { credit accident \& health, other accident \& } \\
\text { health, auto physical, burglar \& theft, } \\
\text { boiler \& machinery, and credit) }\end{array}$ \\
$\begin{array}{l}\text { Opaque Assets (mortgage loans, real estate } \\
\text { investment, premium notes, premiums } \\
\text { receivable, other investments, and } \\
\text { reinsurance recoverable on loss and loss } \\
\text { adjustment expense payments) }\end{array}$ & $\begin{array}{l}\text { worker's compensation, other liabilities, } \\
\text { private and commercial auto liability, } \\
\text { aircraft, fidelity, surety, international, and } \\
\text { reinsurance assumed) }\end{array}$ \\
\hline
\end{tabular}

underwriting lines. Polonchek and Miller's (1999) finding that market reactions to equity offerings by insurers are greater than those for similar offerings by commercial banks offers empirical support for the direction of our study.

\section{Adverse Selection Models}

Researchers have developed several models to decompose the bid-ask spread into its various components, one of which is adverse selection. ${ }^{2}$ The adverse selection component of the spread represents the compensation to the market maker for dealing

\footnotetext{
${ }^{2}$ The adverse selection models of Stoll (1989) and Huang and Stoll (1997) decompose the spread into three components: inventory holding costs, order processing costs, and adverse selection costs. There also are spread components models that use two components (see, e.g., George, Kaul, and Nimalendran, 1991; Glosten and Harris, 1988). In all of these models (two- and three-component models), one of the components is adverse selection.
} 
with informed traders. Van Ness, Van Ness, and Warr (VVW) (2001) examine the adverse selection component of the spread of five widely used spread decomposition models by comparing adverse selection component estimates to other measures that the authors identify as correlated with adverse selection. ${ }^{3}$ Van Ness, Van Ness, and Warr find that the Glosten and Harris (1988) model has the largest number of predicted relations, but a few of the other models, including the George, Kaul, and Nimalendran (1991) (GKN) and Madhavan, Richardson, and Roomans (1997) model also perform well. FKN indicate both the models of GKN and Lin, Sanger, and Booth (1995) have similar power in explaining the effects of bank asset components on microstructure properties. Given the findings of Van Ness, Van Ness, and Warr and FKN, we apply the GKN model to determine adverse selection. ${ }^{4}$

GKN use the differences between transaction price returns and quote midpoint returns to mitigate the downward bias caused by the time variation in expected returns. This bias should have the same impact on both transaction returns and quote midpoint returns. Hence, the difference between the two returns filters out serial dependence. Transaction return therefore is defined as

$$
T R_{t}=E_{t}+\pi\left(s_{q} / 2\right)\left(Q_{t}-Q_{t-1}\right)+(1-\pi)\left(s_{q} / 2\right) Q_{t}+U_{t}
$$

where $E_{t}$ is the expected return from time $t-1$ to $t ; \pi$ and $(1-\pi)$ are the fractions of the spread due to order processing costs and adverse selection costs, respectively; $s_{q}$ is the percentage bid-ask spread; $Q_{t}$ is a $+1 /-1$ buy-sell indicator; and $U_{t}$ represents public information innovations.

GKN assume that the midpoint of the quote is measured immediately following a transaction at time $t$. An upper case $T$ subscript is used to designate the timing distinction for the quote midpoint. Therefore, the quote midpoint return is

$$
M R_{T}=E_{T}+(1-\pi)\left(s_{q} / 2\right) Q_{T}+U_{T}
$$

Taking the difference between the midpoint return from the transaction return and multiplying by two produces

$$
2 R D_{t}=\pi s_{q}\left(Q_{t}-Q_{t-1}\right)+V_{t}
$$

where $V_{t}=2\left(E_{t}-E_{T}\right)+2\left(U_{t}-U_{T}\right)$. Relaxing the assumption that $s_{q}$ is constant and including an intercept results in

$$
2 R D_{t}=\pi_{0}+\pi_{1} s_{q}\left(Q_{t}-Q_{t-1}\right)+V_{t}
$$

\footnotetext{
${ }^{3}$ The five models are: Glosten and Harris (1988), GKN, Huang and Stoll (1997), Lin, Sanger, and Booth (1995), and Madhavan, Richardson, and Roomans (1997).

${ }^{4}$ Originally, we used GKN, Glosten and Harris (1988), and Lin, Sanger, and Booth (1995) model. For ease of reporting, we provide only the GKN results, as justified by the findings of Van Ness, Van Ness, and Warr (2001) and FKN. The results from the other models are qualitatively similar to those presented here.
} 
After estimating the above equation with ordinary least squares (OLS) regression, we obtain the adverse selection component as the fraction of spread estimated by $1-\hat{\pi}_{1}$.

\section{Data ANd Method}

\section{Data Sources and Sample Selection}

Our sample period is January 1, 1996 through December 31, 2004. We first identify insurers trading on the NYSE (Standard Industrial Classification (SIC) codes 6300 through 6399). After omitting insurers that experience a merger, acquisition, or listing change during the time period and firms for which data are incomplete, we have a sample with over 700 firm-years of data. ${ }^{5}$ We then select the insurers for which institutional holding data are available from the Standard \& Poor's Security Owner's Stock Guide. ${ }^{6}$ We obtain data for financial analysts' consensus earnings forecasts from First Call's I/B/E/S database. We specifically apply analysts' last earnings forecasts at the end of the year for next year's earnings per share (EPS). We obtain actual EPS at the end of each year from the Compustat database.

We collect stock quote and trade data from the NYSE Trade and Quote (TAQ) database for the ordinary trading period of 9:30 A.M. to 4:00 P.M. (Eastern Time). Our operational data for insurers is taken primarily from the A.M. Best Statement File database, which allows us to retrieve consolidated data for both P-C and L-H insurers. ${ }^{7}$ We also use SNL DataSource, a database dedicated to the financial services sector, to obtain information about insurers' financial borrowings. Considering that some conglomerate companies may provide a comprehensive range of products and services, we check the percentage of insurance activities in the whole business mix with Securities and Exchange Commission's EDGAR database. A company must have insurance operations generating 50 percent or more of total revenues to be included in our sample.

\section{Factors Affecting Adverse Selection}

Based upon research pertaining to insurance, market microstructure, and corporate finance, we group factors affecting spreads, of which adverse selection is a component, into five categories: market microstructure, corporate finance, informed trader, asset composition, and line of business. We subsequently discuss the factors in each category and their effects on bid-ask spreads.

\section{Market Microstructure Factors}

Market microstructure research shows that price, activity, competition, and volatility are determinants of spreads (Tinic and West, 1972; McInish and Wood, 1992). These

\footnotetext{
${ }^{5}$ The total sample ranges from a high of 96 firms in 1 year, to a low of 58 firms in another year. The number of P-C firms runs from a high of 58 firms to 44 firms. All results were also rerun with only the firms that were in the sample for the entire time period (a balanced panel data set, as opposed to the results reported here in an unbalanced panel). The results were qualitatively similar.

${ }^{6}$ If no data for an insurer are listed in the Standard \& Poor's Security Owner's Stock Guide, this does not necessarily mean that no institutional investors hold that insurer's stock.

${ }^{7}$ We do not use the broader NAIC InfoPro database because it does not provide group data for L-H insurers.
} 
factors must be controlled for when examining the adverse selection component of spreads.

Trading Volume. High trading volume implies an increased probability that an informational event has occurred and further increases the probability of subsequent trading (Easley and O'Hara, 1992). Because market makers can infer that informed traders use trading volume as a signal of new information, volume should be positively related to the spread and the adverse selection component of the spread.

Harris and Raviv (1993) assume that high trading volume arises from speculative trading. Because high volume may imply the arrival of public limit orders on both sides of the spread, there is a negative relation between volume and spread. In contrast, Conrad and Niden (1992) examine corporate acquisition announcements and find no significant relation between trading volume and the adverse selection component of the spread. Prior research results therefore prevent us from predicting the direction for this variable. We include the average daily trading volume and the standard deviation of average daily trading volume to measure volume and changes in volume, respectively.

Price. Demsetz (1968) regards the bid-ask spread as a mark-up that is compensation for predictable immediacy of exchange in organized markets. Based upon a competitive equilibrium model, he notes that there is a positive relation between price and the absolute dollar value of the spread, and concludes that higher spreads are needed to equalize the higher transaction cost per dollar exchanged. More recent studies (Stoll, 1978, 2000; Chan, Christie, and Schultz, 1995) find a negative relation between price and percentage spread. Stoll (1978) provides three reasons for a negative relation. First, scale economies exist because order processing costs are spread over more dollars for high-priced stocks. Second, minimum tick size (one-eighth at that time) can cause low-priced stocks to have artificially high spreads. Third, some evidence indicates that price is negatively correlated with risk, so the dealer charges relatively smaller spreads to hold higher-priced stocks. Based upon the more recent research, we expect a negative relation between price and adverse selection.

Volatility. Volatility has long been recognized as an appropriate proxy for risk (Schwartz, 1988). Stoll (1978) and Ho and Stoll (1981) develop inventory models indicating that higher volatilities of stock prices increase the inventory risk exposure of the market maker, and the market maker therefore needs higher spreads to make up for holding costs.

Copeland and Galai (1983) interpret spreads as a result of the trade-off between expected losses to informed traders and expected gains from liquidity traders. Because market makers wish to maximize their profits, the higher specific risk of the stock measured by return volatility increases the expected total cost function. As the expected losses shift upward, the equilibrium ask prices are raised and so are the bid-ask spreads. Karpoff $(1986,1987)$ and Krinsky and Lee $(1996)$ show a positive relation between trading volume and share price volatility in information-revealing events such as earnings announcements. Volatility therefore may affect bid-ask spreads in a manner similar to that for volume. In empirical studies, different definitions of volatility have been proposed to capture volatility and we choose two: the volatility of daily stock return (Van Ness, Van Ness, and Warr, 2001) and the variability of midpoint of 
bid-ask quotes (McInish and Wood, 1992). Based on the preponderance of previous research we expect a positive effect on our dependent variables.

\section{Corporate Finance Factors}

To account for the informational opaqueness driven by agency costs (Ross, 1989) and variation of firm-specific characteristics, we include several corporate finance factors. These factors are growth, financial leverage, underwriting leverage, and firm size.

Growth. The pecking order hypothesis of Myers and Majluf (1984) assumes that managers are looking out for the interests of current shareholders. Under informational asymmetry, firms with favorable growth opportunities will decline to issue new equity if it would lead to a wealth transfer from old to new shareholders. As a result, one implication of the pecking order hypothesis is that firms with greater growth opportunities are associated with greater information asymmetry. Moreover, it is harder for investors to estimate the future cash flows of growing entities, which may induce greater informational asymmetry (Van Ness, Van Ness, and Warr, 2001). The marketto-book ratio is a common proxy for firm growth (Barclay and Smith, 1995; Berk, Green, and Naik, 1999) and recent research indicates a negative relation with bid-ask spreads. We therefore measure our growth opportunity proxy, as follows:

$$
\text { Market-to-Book Ratio }=\frac{\text { Market Value of Equity }+ \text { Book Value of Debt }}{\text { Book Value of Assets }} .
$$

Financial Leverage. Jensen and Meckling (1976) indicate that debt can engender the following agency costs: (1) wealth transfers from debt holders to owner-managers by asset substitution, (2) monitoring costs, and (3) direct or indirect bankruptcy costs related to the fixed claim of debt holders. These agency costs often are unlikely to be transparent to investors. High financial leverage therefore should increase informational opaqueness and, subsequently, the adverse selection component of the spread. On the other hand, high financial leverage can reduce agency costs by decreasing the free cash flow when firms make regular payments to debt holders (Jensen, 1986; Stulz, 1990). Since the empirical evidence from Van Ness, Van Ness, and Warr (2005) is more consistent with Jensen and Meckling's model, we expect financial leverage to have a positive effect on adverse selection costs. Financial leverage is measured as the ratio of total debts to total assets.

Underwriting Leverage. We decompose insurer revenue flows as follows:

$$
\begin{aligned}
\text { ROE } & =\frac{\text { Net Income }}{\text { Equity }}=R_{A} * \frac{\text { Asset }}{\text { Equity }}+R_{U} * \frac{\text { Premium }}{\text { Equity }} \\
& =R_{A} *\left(\frac{\text { Liability }}{\text { Premium }} * \frac{\text { Premium }}{\text { Equity }}+1\right)+\frac{\text { Premium }}{\text { Equity }} * R_{U},
\end{aligned}
$$

where $R_{A}=$ rate of return on assets and $R_{U}=$ rate of return on underwriting premium. A measure of insurance underwriting risk, known as underwriting leverage (Garven and Pottier, 1995; Black and Skipper, 2000), therefore can be estimated with the ratio of underwriting revenues to insurer surplus. This ratio reflects the risk of surplus depletion when adverse claims experience develops. Higher underwriting 
leverage indicates a lower capacity to write new policies or an equivalently higher loss possibility based on the current capital level. Similar to the impact of fixed debt, larger underwriting liabilities derived from unfavorable loss experience create the predominant bankruptcy risks assumed by most insurers (Cox and Griepentrog, 1988; Cummins, 1991; Chamberlain and Tennyson, 1998) and accordingly produce higher informational opaqueness. We consequently expect that high underwriting leverage will increase the spread and adverse selection component.

Size. We expect a negative relation between adverse selection and size for two reasons. First, to the extent that some costs of information collection are fixed, economies of scale can induce investors to follow and take larger positions in stocks of bigger firms (Van Ness, Van Ness, and Warr, 2005). Second, observing that small stock prices react slowly to new information, Merton (1987) argues that small firms may have higher levels of informational opacity because they receive relatively little attention from investors and analysts. We measure firm size as the market value of equity.

\section{Informed Trader Factors}

Kyle (1985) provides a dynamic model to show that inside traders with superior information impose significant costs on noise traders and market makers. ${ }^{8}$ In the spirit of Glosten and Milgrom (1985) and Kyle (1985), Admati and Pfleiderer (1988) establish a trading model and show that an increase in the number of informed traders will improve market depth as measured by the reciprocal of the coefficient estimate of price change regressed on order flow. In this study, we implement measures of financial analyst activity and institutional activity as our proxies for informed traders.

Analyst Activity. Using the number of financial analysts covering a company as a proxy for informed traders, Brennan and Subrahmanyam (1995) examine the relation between the number of informed traders and the estimated adverse selection cost after controlling for other market microstructure variables. ${ }^{9}$ They find that greater analyst coverage reduces adverse selection costs because of enhanced competition between informed traders, so their results are consistent with Admati and Pfleiderer's model. Brennan, Jegadeesh, and Swaminathan (1993) discover that stocks covered by a greater number of analysts react faster to common information than stocks covered by a smaller number of analysts.

Brennan and Tamarowski (2000) show that increases in analyst coverage improve liquidity because enhanced competition between informed traders reduces the asymmetric information component of the bid-ask spread. Irvine (2003) finds that liquidity improves after analysts initiate coverage, and he argues that this is consistent with the liquidity-improving hypothesis of Brennan and Subrahmanyam (1995). Chung et al. (1995) use a simultaneous equations system to estimate the relation between spread size and the number of analysts, and find that there is a positive relation between the number of analysts covering a stock and the size of the spread, an important component of liquidity.

\footnotetext{
${ }^{8}$ Noise traders are usually investors who make buy and sell decisions without fundamental analysis. They generally have poor timing, follow trends, and overreact to good and bad news. ${ }^{9}$ They estimate adverse selection costs using the models of Glosten and Harris (1988) and Madhavan and Smidt (1991).
} 
The conflicting hypotheses and empirical results described previously prevent us from predicting the impact of the number of analysts on spreads. A related variable, the divergence in financial analysts' forecasts, should result in larger adverse selection costs, however. This is because forecast deviation and error can be driven by either private information (Kim and Verrecchia, 1994) or differences of opinion (Harris and Raviv, 1993), both of which affect informational opacity.

We apply three proxies for analyst activity: the number of financial analysts covering a company, the dispersion of earnings forecasts, and the analyst forecast error. The latter two variables are defined as follows:

$$
\begin{gathered}
\text { DISPERSION }=\left|\frac{\text { Standard Deviation of Estimate }}{\text { Median Estimate }}\right|, \\
\text { ERROR }=\left|\frac{\text { Actual EPS }- \text { Median EPS }}{\text { Actual EPS }}\right| .
\end{gathered}
$$

If no analyst follows a particular insurer, we define dispersion to be zero, and the error to be one.

Institutional Activity. In addition to the number of analysts covering a stock, Van Ness, Van Ness, and Warr (2001) examine institutional holdings as another proxy for informed trading that could affect spread and adverse selection. They argue that a larger number of institutions owning a stock indicate less private information because competitive trading between institutions often reveals such information. They find significantly negative relations between the number of institutions holding a stock and three alternative estimates of adverse selection costs.

Institutional trades contain more information than noise trades. If the information contained in the institutional trades is not publically available then an increase in institutional trades should increase adverse selection costs. Lin, Sanger and Booth (1995) find an increasing and nonlinear relation between spread and trade size. We follow Brennan and Subrahmanyam (1995) and Van Ness, Van Ness, and Warr (2001) in exploring whether institutional trading has any information content beyond such microstructure variables as price and volume. Based upon the conflicting results from previous studies, we cannot predict the impact of this variable. We estimate institutional activity with two proxies: the number of institutions that hold a company's stock and the percentage of institutional holdings.

\section{Asset Composition Factors}

Researchers investigating banks suggest that these financial institutions own private information about the quality of loans that allow managers to minimize monitoring costs and mitigate moral hazard problems when contracting with borrowers (Lummer and McConnell, 1989; Diamond 1984, 1989, 1991). Empirical support is provided by the event studies of James (1987) and Lummer and McConnell (1989). Morgan (2002) shows that for samples of banks, bond raters disagree more when greater amounts of opaque assets, such as loans, are held.

(FKN) posit that if microstructure variables reflect opaqueness, they should vary systematically across banks with different balance sheet compositions. They apply 
six exclusive categories to test the information asymmetries impounded in bank asset portfolios. ${ }^{10}$ FKN define the most opaque banking assets as loans, loss allowances, real estate investment, and other investment. Curiously, they then test the relative amount of transparent assets, rather than opaque assets, as their primary variable of interest.

Following the principles of FKN, we define opaque and transparent assets as shown in Table $1 .{ }^{11}$ We expect a positive relation between opaque assets and adverse selection.

\section{Line-of-Business Factors}

While the major asset risks of banks and insurers should be somewhat similar, liability exposures are very different. Specifically, the underwriting risk of insurers produces a more complicated risk profile. Bank liabilities are mainly composed of commercial paper, demand and time deposits, certificates of deposit, and bonds. The payouts on these liabilities are often fixed obligations and, therefore, cash flows are highly predictable. This explains why research on the informational asymmetry of banks focuses on asset, rather than liability, compositions (see, e.g., Campbell and Kracaw, 1980; Diamond, 1984, 1991).

In contrast to banks, the obligations underwritten by insurers have different risk characteristics that often generate greater uncertainty. Insurance contracts vary with respect to uncertainty in both the timing and amount of payouts. Phillips, Cummins, and Allen (1998) investigate pricing models for multiple lines of P-C insurers by categorizing the business mix into short- and long-tailed lines. They consider the lines that pay out 90 percent of claims within 3 years to be short tailed, and lines that take longer time to be long tailed. Generally, property insurance lines, such as auto physical damage and fire damage have relatively short tails with most claims being settled within a matter of months.

Liability LOB generally have longer tails of claims payments as claims often emerge and are settled over many years. For example, workers' compensation and medical malpractice lines tend to have among the longer settlement tails. Cummins and Lamm-Tennant (1994) generate evidence of higher equity costs for P-C insurers writing long-tail lines, and conclude that long-tail lines are more risky than short-tailed lines primarily because of information asymmetry. Such asymmetry implies opaqueness because the actual values of long-tailed liabilities are relatively difficult to assess.

The accuracy of loss estimation also depends on the LOB underwritten. Managers face difficulty in estimating losses in P-C lines for which loss experience is limited, such as terrorism insurance (U.S. General Accounting Office, 2002), or for which rapid changes in the legal-political environment occur, such as medical malpractice insurance (U.S. General Accounting Office, 1999). Some accident and health products

\footnotetext{
${ }^{10}$ These categories are total loans, loan loss allowance, fair value of assets held in trading accounts, other real estate owned, book value of bank premises and fixed assets plus other assets, and transparent assets.

${ }^{11}$ Although cash, stock, and bonds also are important components of the separate accounts for life insurers, separate accounts also include mortgage loans and real estate. Our data do not allow us to identify these different investments within the separate accounts so we exclude all separate accounts from our proxies.
} 
generate similar estimation problems because of changing legislative and regulatory environments, extraordinary legal expenses, and inflation of medical expenses (Cox and $\mathrm{Ge}, 2004)$. In contrast, life and annuity products are supported by well-developed mortality tables and other advanced demographic statistics, so life insurers can accurately estimate the timing and amount of claims, even though many have lengthy maturities (American Academy of Actuaries, 2002).

We classify insurer LOB into opaque and transparent liability categories as shown in Table 1. Among all products underwritten by L-H insurers, Baranoff and Sager (2002) consider accident and health to be the line for which insurers have the greatest difficulty in estimating ultimate losses while annuities are the easiest to estimate because of the fixed nature of the obligation and well-defined actuarial tables. Regulators apparently agree as the National Association of Insurance Commissioners (NAIC) assigns a larger weight to accident and health insurance than life insurance and annuities in the risk-based capital formula for insurers (NAIC, 2007). Cummins, Tennyson, and Weiss (1999) also argue that accident and health insurance is more similar to liability insurance rather than to savings products such as annuities. Citing transaction cost economics (Williamson, 1985), Baranoff and Sager (2003) suggest that group accident and health business is riskier than individual lines, as the former uses relational contracts that are complex and uncertain while the latter uses classical contracts that are standardized and simple. Following the extant research, we initially classify group accident and health lines as opaque, while life insurance and annuities are considered transparent. ${ }^{12,13}$

For P-C LOB, we generally regard short-tailed lines as more transparent and the resulting liabilities easier to estimate while long-tailed lines are more opaque and difficult to estimate. Phillips, Cummins, and Allen (1998) develop a list of short-tailed and long-tailed LOB. The short-tailed LOB include fire, allied lines, earthquake, group accident and health, credit accident and health, other accident and health, auto physical, mortgage guaranty, financial guaranty, inland marine, fidelity and surety, burglar and theft, and credit insurance. The long-tailed LOB consist of medical malpractice, worker's compensation, auto liability, products liability (occurrence/claims made), other liability, boiler and machinery, aircraft, ocean marine, farmowners multiple

\footnotetext{
${ }^{12}$ We maintain the traditional view of life insurance and annuity liabilities in that we expect these values to reflect relatively accurate, current, and well-known actuarial and interest rate structures. Several researchers explain how outdated or nonrepresentative actuarial methods and interest rate structures applied by life insurers introduce risk to embedded options such as policy loans, settlement options, and surrender or renewal provisions. Insurers can protect against such risk by revising policy provisions and using more sophisticated technology (Santomero and Babbel, 1997; Grosen and Jorgensen, 2002), as well as by hedging with derivatives (Hentschel and Smith, 1997). We have no way to estimate the risk engendered by embedded options, so to the extent that they are in place, opaque, and not fully hedged, these options can confound our results.

${ }^{13}$ An argument can be made that less asymmetry exists in group accident and health lines than in individual accident and health because the large numbers of insureds in groups makes losses more predictable. For robustness purposes, we also use the "other accident and health" category in the NAIC database to estimate and test individual accident and health exposure as a substitute for group accident and health in our LOB opaqueness variables. These tests, not reported here, generate only small, insignificant differences in our ultimate results.
} 
peril, homeowners multiple peril, commercial multiple peril, international, and reinsurance. In an earlier article, Cummins and Lamm-Tennant (1994) test the effects of specializing in commercial long-tailed lines that include workers' compensation, auto liability and other liability on P-C insurer stock betas. We use both restricted (Cummins and Lamm-Tennant, 1994) and broad (Phillips, Cummins, and Allen, 1998) classifications of long-tailed lines to test the effect of informational opacity caused by two different characteristics. In addition, we use an even broader proxy for long-tailed P-C lines by adding A\&H premiums underwritten by P-C insurers to Phillips, Cummins, and Allen's (1998) classification because A\&H contracts, while shorter term, can be more relational and difficult to value (Baranoff and Sager, 2002, 2003).

We construct several proxies to measure LOB impact. $L H O P A$ is the percentage of premium from the opaque LOB to total premiums for L-H insurers. PCOPA1 is the percentage of premium from relatively opaque, long-tailed LOB to total premiums for P-C insurers based on Cummins and Lamm-Tennant's (1994) classification. PCOPA2 is the percentage of premium from nontransparent LOB to total premiums for P-C insurers based on Philips, Cummins, and Allen's (1998) classification. Finally, PCOPA3 modifies PCOPA2 by incorporating accident and health premiums.

\section{Method}

We first implement a single equation regression to examine the impact of information asymmetry variables on adverse selection components. Then, we control for possible endogeneity problems of variables such as analyst activity and trading volume by using a three-equation system.

To test the relation between the adverse selection component of the spread and the information asymmetry variables, we initially regress the following equation using fixed effects and random effects models applied to data for each insurer $i$ at time period $t$

$$
\begin{aligned}
A S_{i t}= & \beta_{0}+\beta_{1} \text { VOM }_{i t}+\beta_{2} \text { STDVOM }_{i t}+\beta_{3} \text { PRICE }_{i t}+\beta_{4} \text { LNMID }_{i t} \\
& +\beta_{5} \text { LNSDRE }_{i t}+\beta_{6} \text { LNMVE }_{i t}+\beta_{7} \text { LNMB }_{i t}+\beta_{8} \text { FINLEV }_{i t} \\
& +\beta_{9} \text { UNDLEV }_{i t}+\beta_{10} \text { LNINST }_{i t}+\beta_{11} \text { LNPINST }_{i t}+\beta_{12} \text { LNANST }_{i t} \\
& +\beta_{13} \text { DISP }_{i t}+\beta_{14} \text { ERROR }_{i t}+\beta_{15} \text { OPAAST }_{i t}+\beta_{16} \text { LHOPA }_{i t} \\
& +\beta_{17} \text { PCOPA }_{i t}+\varepsilon_{i t},
\end{aligned}
$$

where

$A S=$ the adverse selection component of the spread using the GKN model, scaled by price

$V O M=\ln ($ average daily trading volume)

$S T D V O M=\ln ($ standard deviation of average daily trading volume)

$P R I C E=\ln ($ stock price)

$L N M I D=\ln ($ variance of spread midpoint $)$ 


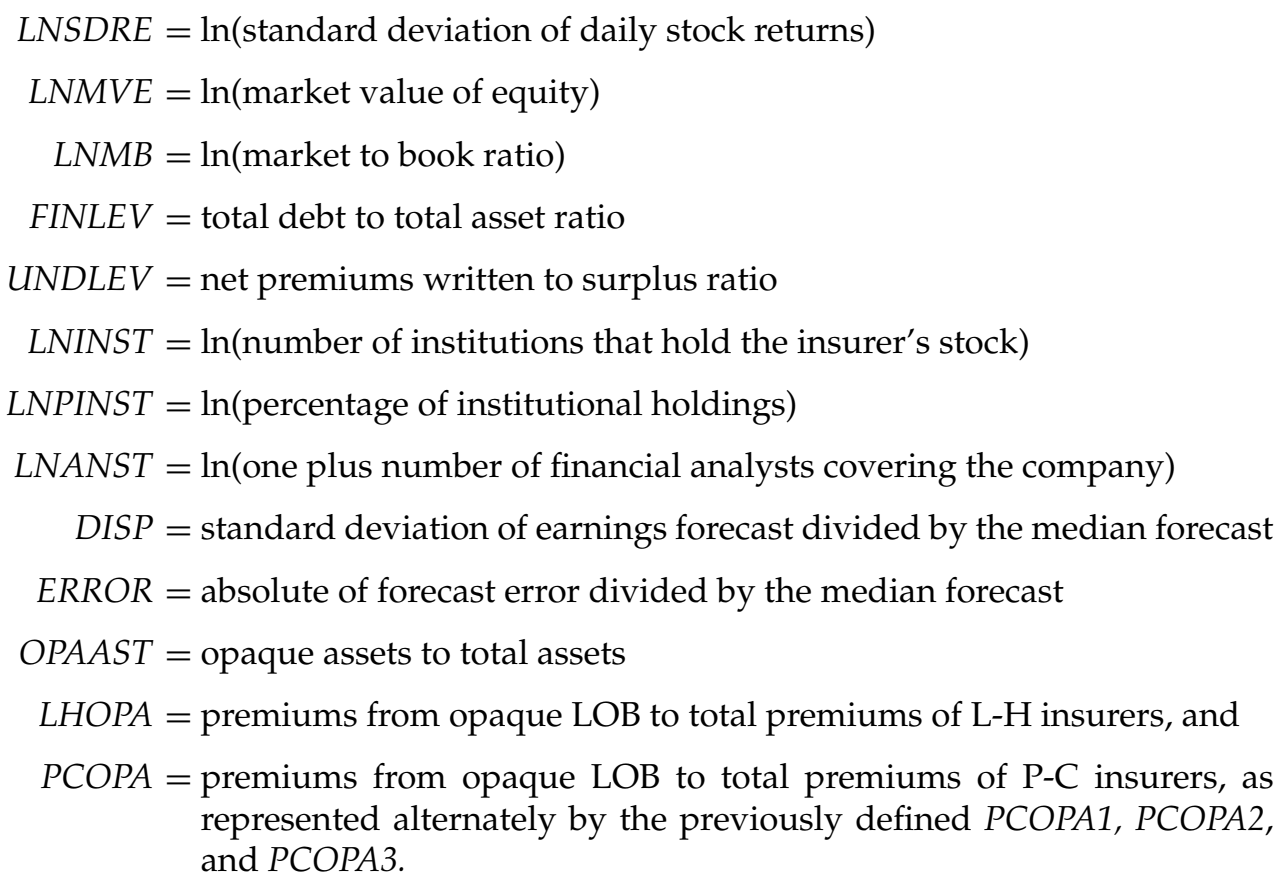

We run the models using the adverse selection estimates suggested by the GKN model as the dependent variable. Following Brennan and Subrahmanyam (1995) and Van Ness, Van Ness, and Warr (2001), we express the adverse selection component as a percentage of the stock price, thus we control for stock price. We also implement the Hausman specification test to verify whether the random effects model is consistent and efficient for our sample.

In the single-equation regression, the independent variables are assumed to be independent of error terms. To the extent that financial analysts' earnings forecast and volume are simultaneously determined with the spread or adverse selection components, traditional regressions may yield biased and inconsistent results. For example, stocks with a greater number of covering analysts have greater transparency because more information is produced while, at the same time, stocks with greater informational opacity can attract more analysts to capitalize on inefficient valuation. Similarly, stocks with large trading volume may be frequently traded by institutions thereby generating more information content, while stocks with greater information opacity may be traded in high volume by investors possessing superior information. Admati and Pfleiderer (1988) posit that the number of informed traders is not an exogenous variable and should be determined by the trade-off of becoming informed.

We address potential endogeneity problems in our original regression because trading volume and the number of analysts following a stock can influence adverse selection (Brennan and Subrahmanyam, 1995; Van Ness, Van Ness, and Warr, 2001). We use 
the following simultaneous equations system based upon the framework provided by these researchers

$$
\begin{aligned}
& A S_{i t}=\beta_{0}+\beta_{1} \text { VOM }_{i t}+\beta_{2} \text { STDVOM }_{i t}+\beta_{3} \text { PRICE }_{i t}+\beta_{4} L_{\text {LNMID }} \\
& +\beta_{5} L N S D R E_{i t}+\beta_{6} \text { FINLEV }_{i t}+\beta_{7} \text { UNDLEV }_{i t}+\beta_{8} \text { LNINST }_{i t} \\
& +\beta_{9} \text { LNPINST }_{i t}+\beta_{10} \text { LNANST }_{i t}+\beta_{11} \text { DISP }_{i t}+\beta_{12} \text { ERROR }_{i t} \\
& +\beta_{13} \mathrm{OPAAST}_{i t}+\beta_{14} \mathrm{LHOPA}_{i t}+\beta_{15} \text { PCOPA }_{i t}+\varepsilon_{\text {LTCit }} \text {, } \\
& \text { LNANST }_{i t}=\eta_{0}+\eta_{1} A S_{i t}+\eta_{2} L_{N M I D} i t+\eta_{3} L_{N M B} B_{i t}+\eta_{4} \text { PRICE }_{i t} \\
& +\eta_{5} \text { LNINST }_{i t}+\eta_{6} \text { LNPINST }_{i t}+\varepsilon_{\text {LN_ANSTit }}, \\
& V O M_{i t}=v_{0}+v_{1} A S_{i t}+v_{2} L N A N S T_{i t}+v_{3} L N M V E_{i t}+v_{4} L N I N S T_{i t} \\
& +\nu_{5} L_{N P I N S T} \text { it }+\varepsilon_{\text {LN_VOMit }} \text {. }
\end{aligned}
$$

We modify our primary model Equation (10) only slightly from that of Van Ness, Van Ness, and Warr (2001). The uncertainty variables used by Van Ness, Van Ness, and Warr, the ratio of intangible assets to total assets and the ratio of research and development expenditures to sales, are omitted as these apply to industrial firms and no comparable data are available for insurers. We include three additional variables that we believe are related to adverse selection for insurers in Equation (10). Because asset transparency should be related to adverse selection we include a variable (OPAAST) for the ratio of opaque assets to total assets. Similarly, we incorporate LHOPA and the alternative proxies for PCOPA, as defined in Equation (9), to impound the effects of varying levels of asymmetric information and resulting opaqueness across different LOB.

Equation (11) (the second equation in our simultaneous equation approach) examines the relation between the number of analysts with adverse selection, the standard deviation of the spread midpoint, firm size, price, and variables that measure institutional activity. The only variation of our second equation and that of Van Ness, Van Ness, and Warr (2001) is that we eliminate the industry dummies because our sample is restricted to insurers.

The third and final equation in our simultaneous equation system, Equation (12) relates volume to adverse selection, the number of analysts, firm market value, and institutional activity. We make no modifications to the third equation used in the Van Ness, Van Ness, and Warr (2001) model.

We apply a 3SLS fixed effects model suggested by Greene (1995) to estimate the simultaneous equations model. ${ }^{14}$ To further test the robustness of our results, we

\footnotetext{
${ }^{14}$ We run both random and fixed effects models. The Hausman tests show that the fixed effects models were superior to the random effects models Therefore, we only report the fixed effects models.
} 
then regress Equations (9) through (11) with data only for all P-C insurers listed on the NYSE, omitting the variables representing L-H LOB (LHOPA). ${ }^{15}$

\section{EMPIRICAL Results}

Summary Statistics

Table 2 presents summary statistics for our sample of insurance stocks. We see that adverse selection comprises 46.3 percent of the spread for insurance stocks, so it is a significant portion of the quoted spread. ${ }^{16}$ Among the market microstructure variables, trading volume and volume volatilities are relatively stable for the NYSE insurance stocks. The market-to-book ratios for insurance stocks traded on the NYSE generally have a value less than one, which reflects a relatively low-growth industry.

The statistics further indicate that NYSE-listed insurers use both high financial and underwriting leverage, with the mean debt ratio exceeding 60 percent and premiums written over two times surplus. The insurance stocks listed on the NYSE generally are covered by more than one financial analyst and earnings forecasts are extensively dispersed, as evidenced by the high relative standard deviation. The large number of covering financial analysts suggests more information and less adverse selection for NYSE-listed insurance stocks, but the large number of institutional holdings should have an opposing effect. On the asset side, opaque assets account for slightly less than 20 percent of total assets for these insurers. On the underwriting liability side, about one third of total P-C insurance premiums are underwritten in opaque business lines, while the comparable proportion for $\mathrm{L}-\mathrm{H}$ insurers is only 11 percent.

\section{Single Equation Regression Results}

Table 3 presents single equation regressions of adverse selection on variables representing market microstructure, corporate finance, asset composition, and LOB. The coefficients of volume are negative and significant, which supports Harris and Raviv's (1993) finding that higher volume is associated with new information, therefore, lower adverse selection. Furthermore, the coefficients of price are negative and significant, which is consistent with the findings of Stoll $(1978,2000)$ and Chan, Christie, and Schultz (1995). Coefficients for volume volatility and daily return volatility are both positive and significant.

Among the four corporate finance factors, we find that the coefficients of size are insignificant and this contrasts with the findings of Van Ness, Van Ness, and Warr (2001). The coefficients for the market-to-book ratio are both negative and insignificant. Our results consequently do not support a positive relation between growth opportunities and adverse selection for insurers. The coefficients for financial leverage and underwriting leverage also are insignificant.

\footnotetext{
${ }^{15}$ Our original data set comes from NAIC InfoPro, which reports consolidated P-C insurers' data but not consolidated L-H insurers' data.

${ }^{16}$ This 46.3 percent of the spread is lower than the 70 percent of the spread found by FKN for banking stocks, but higher than the 38.9 percent of the spread found by Van Ness, Van Ness, and Warr (2001) for a broad selection of NYSE-listed stocks.
} 


\section{TABLE 2}

\section{Selected Statistics}

\begin{tabular}{|c|c|c|c|c|c|}
\hline & Mean & Std. Dev. & Median & Max & Min \\
\hline \multicolumn{6}{|c|}{ Adverse selection component as proportion of the spread } \\
\hline GKN & 0.462 & 0.107 & 0.480 & 1.000 & 0.000 \\
\hline \multicolumn{6}{|c|}{ Market microstructure factors } \\
\hline$V O M$ & 11.712 & 1.681 & 11.892 & 15.714 & 7.627 \\
\hline STDVOM & 7.481 & 0.838 & 7.556 & 10.168 & 5.166 \\
\hline PRICE & 3.440 & 0.805 & 3.470 & 6.247 & 0.604 \\
\hline LNMID & 1.370 & 0.931 & 1.352 & 4.187 & -1.888 \\
\hline LNSDRE & -3.917 & 0.414 & -3.945 & -1.519 & -5.715 \\
\hline \multicolumn{6}{|c|}{ Corporate finance factors } \\
\hline LNMVE & 9.273 & 3.152 & 8.435 & 17.973 & 3.343 \\
\hline$L N M B$ & -0.600 & 1.134 & -0.278 & 3.042 & -6.001 \\
\hline FINLEV & 0.620 & 0.310 & 0.709 & 2.966 & 0.001 \\
\hline UNDLEV & 2.703 & 11.339 & 1.616 & 270.226 & 0.001 \\
\hline \multicolumn{6}{|c|}{ Informed trader factors } \\
\hline LNANST & 2.988 & 1.336 & 3.219 & 5.236 & 0.000 \\
\hline DISP & 0.171 & 0.414 & 0.051 & 8.109 & 0.000 \\
\hline ERROR & 0.486 & 2.152 & 0.100 & 44.918 & -11.000 \\
\hline LNINST & 4.744 & 1.025 & 4.828 & 7.050 & 0.000 \\
\hline LNPINST & -0.951 & 1.125 & -0.597 & 0.344 & -7.890 \\
\hline \multicolumn{6}{|c|}{ Asset composition factors } \\
\hline OPAAST & 0.192 & 0.124 & 0.170 & 0.860 & 0.001 \\
\hline \multicolumn{6}{|c|}{ Line-of-business factors } \\
\hline LHOPA & 0.109 & 0.294 & 0.000 & 3.649 & 0.000 \\
\hline PCOPA1 & 0.326 & 0.450 & 0.027 & 3.749 & 0.000 \\
\hline РСОРА2 & 0.193 & 0.310 & 0.008 & 3.561 & -0.698 \\
\hline РСОРАЗ & 0.329 & 0.453 & 0.027 & 3.749 & 0.000 \\
\hline
\end{tabular}

Note: GKN is the adverse selection component estimate using the George, Kaul, and Nimalendran (1991) model. VOM = average daily trading volume; STDVOM = standard deviation of average daily trading volume; PRICE = stock price; $L N M I D=$ variance of spread midpoint; $L N S D R E=$ standard deviation of daily stock returns; $L N M V E=$ the natural log of market value of equity; $L N M B=$ the natural $\log$ of market to book ratio; FINLEV = the total debt to total asset ratio; $U N D L E V=$ the net premium to surplus ratio; $L N A N S T=$ the natural $\log$ of one plus number of financial analysts covering the company; DISP = the standard deviation of earnings forecast divided by the median forecast; $E R R O R=$ the absolute of forecast error divided by the median forecast; LNINST = the natural log of number of institutions that hold the company's stocks; LNPINST = the natural log of the percentage of institutional holdings; $O P A A S T=$ ratio of opaque assets to total assets; $L H O P A=$ ratio of premium from opaque lines of business to total premium for life and health insurers; PCOPA $1=$ ratio of premium from opaque lines of business to total premium for property and casualty insurers based on Cummins and Lamm-Tennant's (1994) classification; PCOPA2 = computed like PCOPA1, except using the Philips, Cummins and Allen's (1998) classification; and PCOPA3 = PCOPA2 with $\mathrm{A} \& \mathrm{H}$ premiums included in the numerator. 


\section{TABLE 3}

Single Equation Adverse Selection Regressions for the Adverse Selection Component of Price Spreads

\begin{tabular}{|c|c|c|c|c|c|c|c|}
\hline & $\begin{array}{l}\text { Expected } \\
\text { Sign }\end{array}$ & Coefficient & $t$-statistic & Coefficient & $t$-statistic & Coefficient & t-statistic \\
\hline$V O M$ & \pm & -0.084 & $-1.605^{*}$ & -0.082 & $-1.601^{*}$ & -0.084 & $-1.604^{*}$ \\
\hline STDVOM & + & 0.068 & $1.928^{* *}$ & 0.073 & $1.993^{* *}$ & 0.068 & $1.928^{* *}$ \\
\hline PRICE & - & -0.093 & $-1.931^{* *}$ & -0.092 & $-1.924^{* *}$ & -0.093 & $-1.934^{* *}$ \\
\hline LNMID & + & 0.019 & 0.387 & 0.020 & 0.411 & 0.019 & 0.395 \\
\hline LNSDRE & + & 0.191 & $1.815^{*}$ & 0.183 & $1.740^{*}$ & 0.191 & $1.817^{* *}$ \\
\hline LNMVE & - & 0.040 & 0.556 & 0.039 & 0.542 & 0.041 & 0.558 \\
\hline LNMB & + & -0.063 & -0.644 & -0.066 & -0.674 & -0.064 & -0.648 \\
\hline FINLEV & + & 0.408 & 0.969 & 0.353 & 0.839 & 0.409 & 0.971 \\
\hline UNDLEV & + & 0.0002 & 0.069 & 0.0002 & 0.094 & 0.0002 & 0.067 \\
\hline LNANST & \pm & -0.007 & -0.140 & -0.023 & -0.441 & -0.007 & -0.142 \\
\hline DISP & + & 0.016 & 0.213 & 0.016 & 0.213 & 0.016 & 0.212 \\
\hline ERROR & + & 0.002 & 0.163 & 0.002 & 0.177 & 0.002 & 0.167 \\
\hline LNINST & \pm & 0.157 & 1.360 & 0.168 & 1.458 & 0.157 & 1.359 \\
\hline LNPINST & \pm & 0.023 & 0.342 & 0.026 & 0.386 & 0.023 & 0.342 \\
\hline OPAAST & + & -0.649 & -1.244 & -0.686 & -1.321 & -0.645 & -1.236 \\
\hline LHOPA & + & 0.001 & 0.010 & 0.002 & 0.015 & 0.001 & 0.011 \\
\hline PCOPA1 & + & 0.170 & $1.678^{*}$ & & & & \\
\hline РСОРА2 & + & & & 0.305 & $2.059^{* *}$ & & \\
\hline РСОРАЗ & + & & & & & 0.173 & $1.732^{*}$ \\
\hline No. of obs. & & 691 & & 691 & & 691 & \\
\hline Fixed effects & & Yes & Yes & Yes & Yes & Yes & Yes \\
\hline
\end{tabular}

Note: The dependent variable is the adverse selection component estimate using the George, Kaul, and Nimalendran (1991) model.

*Significant at the 0.10 level. ${ }^{* *}$ Significant at the 0.05 level. ${ }^{* * *}$ Significant at the 0.01 level.

Analyzing proxies for informed trading, we find no significant relations. The results for the asset composition variable indicate no relation between opaque assets and adverse selection. The results for LOB opaqueness are very revealing, however. While we observe no significant effects of opacity in L-H lines, our opaqueness proxies are positive and significant for P-C LOB. Hence, our results suggest that a higher proportion of premiums derived from opaque $\mathrm{P}-\mathrm{C}$ lines raises informational problems for market makers and investors, thereby increasing the costs of adverse selection.

Overall, our hypotheses regarding the expected effects of information asymmetry on adverse selection costs are supported by market microstructure variables such as price, volume, volatility, and volume volatility. LOB opaqueness positively affects adverse selection costs for P-C insurers. We do not observe any such effect for L-H insurers, however, which can be at least partially attributed to the relatively low volume of business written in opaque lines in this segment of the insurance business. Finally, we do not observe a significant effect of asset opacity on adverse selection in the insurer equity market. We reiterate that, on average, insurers hold less than 20 percent of their assets in categories that we can reasonably classify as opaque, however. 


\section{Simultaneous Equations Regression Results}

To address potential endogeneity problems, we reestimate our models using a 3SLS and simultaneous framework (Table 4). We find significant support for the expected effects of volume, volume volatility, and price on adverse selection. Similar to the single-equation results, essentially no relation is observed between leverage ratios, analyst followings, or asset opaqueness and adverse selection costs.

Opaque L-H LOB again have no significant affect on adverse selection in equity markets. Once again, the results are quite different for P-C insurers. A uniformly positive relation between LOB opaqueness and adverse selection is consistently apparent across the alternative LOB measures. The opaqueness measure applying the Philips, Cummins, and Allen (1998) classification again produces the strongest relations.

Our simultaneous equations regressions essentially support our earlier findings. In particular, the results suggest that adverse selection costs are negatively related to stock price and volume, but positively related to volume volatility and P-C LOB opaqueness. In addition, these results indicate a marginally positive impact of stock price volatility on adverse selection costs for insurers in our sample.

The financial analyst equation shows that as the number of financial analysts following a stock increases, the number of institutions that own the stock also increases. The trading volume model reveals that as number of analysts covering the insurer and the number of institutions owning the insurer's stock increases, the volume of trading rises. All of these results are indicative of expected behavior in well-order investment markets.

\section{P-C Insurer Results}

Because the NAIC InfoPro data set provides fully aggregated data for P-C insurers across all insurance divisions, we examine them separately as a robustness check. The results are reported in Table 5. Because most companies in our sample are involved in both $\mathrm{P}-\mathrm{C}$ and L-H insurance business, we define $\mathrm{P}-\mathrm{C}$ insurers as companies with over 50 percent of revenue derived from $\mathrm{P}-\mathrm{C}$ insurance lines. Adverse selection costs are significantly related to trading volume, trading volume volatility, and price, as they were for the entire sample. The significance levels tend to be higher for this reduced sample. Once again, LOB opaqueness is significantly and positively related to adverse selection costs, as it has consistently been for the entire sample. Despite a much smaller sample size the P-C insurer subsample sometimes generates even stronger evidence of the relations we observed previously.

From the financial analyst equation, we find that the number of institutions owning insurer stock is positively related to the number of financial analysts following the stock. The trading volume equation reveals that the number of financial analysts, and number of institutions owning an insurer's stock are all positively related to trading volume, while the relative proportion of the number of institutions holding the insurer's stock is negatively related.

\section{CONCLUSION}

As opposed to research that examines adverse selection between insurers and policyholders, the purpose of this study is to examine adverse selection from the perspective 


\section{TABLE 4}

Simultaneous Equation Regression Results for the Adverse Selection Component of Price Spreads (3SLS)

\begin{tabular}{|c|c|c|c|c|c|c|}
\hline & Coefficient & $t$-statistic & Coefficient & $t$-statistic & Coefficient & $t$-statistic \\
\hline$V O M$ & -0.085 & $-1.98^{* *}$ & -0.084 & $-1.95^{* *}$ & -0.085 & $-1.98^{* *}$ \\
\hline STDVOM & 0.079 & $1.92^{* *}$ & 0.082 & $1.99^{* *}$ & 0.079 & $1.92^{* *}$ \\
\hline PRICE & -0.088 & $-2.09^{* *}$ & -0.088 & $-2.10^{* *}$ & -0.088 & $-2.08^{* *}$ \\
\hline LNMID & 0.020 & 0.50 & 0.021 & 0.54 & 0.020 & 0.49 \\
\hline LNSDRE & 0.150 & $1.82^{*}$ & 0.144 & $1.75^{*}$ & 0.150 & $1.82^{*}$ \\
\hline FINLEV & 0.087 & 0.55 & 0.052 & 0.33 & 0.087 & 0.55 \\
\hline UNDLEV & 0.0004 & 0.20 & 0.0005 & 0.21 & 0.0004 & 0.20 \\
\hline LNINST & -0.006 & -0.15 & -0.016 & -0.40 & -0.006 & -0.15 \\
\hline LNPINST & 0.035 & 0.54 & 0.035 & 0.54 & 0.035 & 0.54 \\
\hline LNANST & 0.002 & 0.14 & 0.002 & 0.15 & 0.002 & 0.14 \\
\hline DISP & 0.165 & $1.81^{*}$ & 0.170 & $1.87^{*}$ & 0.165 & $1.81^{*}$ \\
\hline ERROR & 0.007 & 0.12 & 0.009 & 0.17 & 0.007 & 0.13 \\
\hline OPAAST & -0.534 & -1.39 & -0.561 & -1.47 & -0.538 & -1.40 \\
\hline LHOPA & -0.045 & -0.25 & -0.049 & -0.28 & -0.045 & -0.25 \\
\hline PCOPA1 & 0.148 & $1.67^{*}$ & & & & \\
\hline РСОРА2 & & & 0.289 & $2.20^{* *}$ & & \\
\hline РСОРАЗ & & & & & 0.139 & $1.60^{*}$ \\
\hline \multicolumn{7}{|c|}{ Financial Analyst Equation } \\
\hline & Coefficient & $t$-statistic & Coefficient & $t$-statistic & Coefficient & $t$-statistic \\
\hline AS & -0.024 & -0.57 & -0.015 & -0.47 & -0.024 & -0.54 \\
\hline LNMID & 0.091 & $2.40^{* *}$ & 0.135 & $4.14^{* * *}$ & 0.085 & $2.31^{* *}$ \\
\hline$L N M B$ & 0.146 & $3.18^{* * *}$ & 0.101 & $2.63^{* *}$ & 0.143 & $3.19^{* * *}$ \\
\hline PRICE & 0.020 & 0.47 & -0.022 & -0.68 & 0.021 & 0.50 \\
\hline LNINST & 0.688 & $9.72^{* * *}$ & 0.271 & $3.10^{* * *}$ & 0.687 & $9.69^{* * *}$ \\
\hline LNPINST & 0.169 & $3.06^{* * *}$ & 0.172 & $3.23^{* * *}$ & 0.170 & $3.12^{* * *}$ \\
\hline \multicolumn{7}{|c|}{ Trading Volume Equation } \\
\hline & Coefficient & $t$-statistic & Coefficient & t-statistic & Coefficient & $t$-statistic \\
\hline$A S$ & -0.054 & -1.26 & -0.003 & -0.12 & -0.055 & -1.28 \\
\hline LNANST & 0.092 & $2.25^{* *}$ & 0.091 & $2.58^{* * *}$ & 0.092 & $2.26^{* *}$ \\
\hline LNMVE & 0.034 & 0.95 & -0.028 & -1.10 & 0.034 & 0.95 \\
\hline LNINST & 1.089 & $14.06^{* * *}$ & 0.397 & $5.29^{* * *}$ & 1.088 & $14.02^{* * *}$ \\
\hline LNPINST & -0.175 & $-3.12^{* * *}$ & 0.088 & $1.88^{*}$ & -0.175 & $-3.11^{* * *}$ \\
\hline No. of obs. & 691 & & 691 & & 691 & \\
\hline Fixed effects & Yes & Yes & Yes & Yes & Yes & Yes \\
\hline
\end{tabular}

Note: The dependent variable is the adverse selection component estimate using the George, Kaul, and Nimalendran (1991) model.

*Significant at the 0.10 level. ${ }^{* *}$ Significant at the 0.05 level. ${ }^{* * *}$ Significant at the 0.01 level.

of the secondary capital markets. Market microstructure theory and models allow us to estimate the costs of adverse selection impounded in stock prices, which can be caused by asymmetric information between informed investors, such as managers and inside traders, and uninformed investors, such as market makers and individual 


\section{TABLE 5}

Simultaneous Equation Regression Results for Property and Casualty Insurers Only

\begin{tabular}{lcccccc}
\hline & Coefficient & $t$-statistic & Coefficient & $t$-statistic & Coefficient & $t$-statistic \\
\hline VOM & -0.116 & $-2.70^{* * *}$ & -0.112 & $-2.61^{* * *}$ & -0.116 & $-2.70^{* * *}$ \\
STDVOM & 0.082 & $1.95^{* *}$ & 0.087 & $2.07^{* *}$ & 0.083 & $1.96^{* *}$ \\
PRICE & -0.120 & $-2.91^{* * *}$ & -0.120 & $-2.91^{* * *}$ & -0.119 & $-2.90^{* * *}$ \\
LNMID & -0.011 & -0.26 & -0.009 & -0.21 & -0.011 & -0.26 \\
LNSDRE & 0.144 & $1.70^{*}$ & 0.134 & 1.59 & 0.143 & $1.70^{*}$ \\
FINLEV & 0.241 & 1.18 & 0.167 & 0.81 & 0.241 & 1.19 \\
UNDLEV & -0.0001 & -0.06 & -0.0001 & -0.03 & -0.0001 & -0.06 \\
LNINST & 0.148 & $1.67^{*}$ & 0.153 & $1.73^{*}$ & 0.148 & $1.67^{*}$ \\
LNPINST & 0.015 & 0.28 & 0.018 & 0.34 & 0.015 & 0.28 \\
LNANST & 0.030 & 0.69 & 0.016 & 0.37 & 0.029 & 0.68 \\
DISP & 0.011 & 0.10 & 0.012 & 0.12 & 0.010 & 0.10 \\
ERROR & 0.005 & 0.43 & 0.005 & 0.41 & 0.005 & 0.43 \\
OPAAST & -0.121 & -0.29 & -0.155 & -0.37 & -0.129 & -0.31 \\
PCOPA1 & 0.152 & $2.05^{* *}$ & & & & \\
PCOPA2 & & & 0.265 & $2.39^{* * *}$ & & \\
PCOPA3 & & & & 0.143 & $1.94^{* *}$ \\
\hline
\end{tabular}

\begin{tabular}{|c|c|c|c|c|c|c|}
\hline \multicolumn{7}{|c|}{ Financial Analyst Equation } \\
\hline & Coefficient & $t$-statistic & Coefficient & $t$-statistic & Coefficient & $t$-statistic \\
\hline$A S$ & 0.004 & 0.07 & -0.021 & -0.46 & 0.004 & 0.06 \\
\hline LNMID & 0.126 & $2.65^{* * *}$ & 0.134 & $3.32 * * *$ & 0.125 & $2.61^{* *}$ \\
\hline$L N M B$ & 0.232 & $3.41^{* * *}$ & 0.086 & 1.59 & 0.231 & $3.43^{* * *}$ \\
\hline PRICE & 0.042 & 0.80 & -0.025 & -0.67 & 0.041 & 0.73 \\
\hline LNINST & 0.708 & $8.03^{* * *}$ & 0.232 & $2.39^{* * *}$ & 0.700 & $7.89^{* * *}$ \\
\hline LNPINST & 0.136 & $2.04^{* *}$ & 0.182 & $3.01^{* * *}$ & 0.135 & $2.03^{* *}$ \\
\hline \multicolumn{7}{|c|}{ Trading Volume Equation } \\
\hline & Coefficient & $t$-statistic & Coefficient & t-statistic & Coefficient & $t$-statistic \\
\hline$A S$ & -0.104 & $-1.68^{*}$ & -0.015 & -0.38 & -0.104 & $-1.66^{*}$ \\
\hline LNANST & 0.208 & $4.34^{* * *}$ & 0.174 & $4.09^{* * *}$ & 0.206 & $4.32^{* * *}$ \\
\hline LNMVE & -0.037 & -0.62 & -0.135 & $-3.12^{* * *}$ & -0.030 & -0.53 \\
\hline LNINST & 1.066 & $10.88^{* * *}$ & 0.420 & $5.03^{* * *}$ & 1.064 & $10.74^{* * *}$ \\
\hline LNPINST & -0.204 & $-3.13^{* * *}$ & 0.067 & 1.28 & -0.205 & $-3.12^{* * *}$ \\
\hline No. of obs. & 466 & & 466 & & 466 & \\
\hline Fixed effects & Yes & Yes & Yes & Yes & Yes & Yes \\
\hline
\end{tabular}

Note: The dependent variable is the adverse selection component estimate using the George, Kaul, and Nimalendran (1991) model.

*Significant at the 0.10 level. ${ }^{* *}$ Significant at the 0.05 level. ${ }^{* *}$ Significant at the 0.01 level.

traders. This article extends previous work on adverse selection to insurers, which are unique in that they hold substantial amounts of both relatively opaque assets and liabilities.

We hypothesize that if the adverse selection component of the spread effectively reflects the information asymmetry of a stock, it should be significantly related to variables that reflect information problems, including market microstructure factors 
and financial characteristics of the firm. To increase the robustness of our tests, we apply different proxies for dependent variables, adverse selection costs, and independent variables such as LOB, volatility, and informed trader activity.

While single-equation and traditional panel data regression results provide some support for our hypotheses, our estimates for simultaneous equations and 3SLS models more clearly indicate that for the insurance stocks traded on the NYSE, adverse selection costs have the predicted relations with a number of market microstructure and corporate finance variables. We specifically find that adverse selection costs are positively related to volume volatility, and negatively related to trading volume and price for NYSE insurance stocks. Most notably, our results provide substantial support for the hypothesis that insurers underwriting more opaque LOB are subject to higher adverse selection costs. We find little evidence of a relation between asset opacity and adverse selection, however. Finally, our findings are consistent with predictions that more analyst coverage and larger proportions of holding institutions reduce information asymmetry and, therefore, adverse selection costs generated in the trading of insurance stocks.

\section{RefERENCES}

Admati, A., and P. Pfleiderer, 1988, A Theory of Intraday Patterns: Volume and Price Variability, Review of Financial Studies, 1: 3-40.

American Academy of Actuaries, 2002, Final Report of the American Academy of Actuaries' Commissioners Standard Ordinary Task Force, Presented to the National Association of Insurance Commissioners' Life and Health Actuarial Task Force.

Babbel, D. F., and C. Merrill, 2005, Real and Illusory Value Creation by Insurance Companies, Journal of Risk and Insurance, 72: 1-21.

Bagehot, W., 1971, The Only Game in Town, Financial Analysts Journal, 27: 12-14.

Baranoff, E. G., and T. W. Sager, 2002, The Relationship Between Asset Risk, Product Risk, and Capital in the Life Insurance Industry, Journal of Banking and Finance, 26: 1181-1197.

Baranoff, E. G., and T. W. Sager, 2003, The Relations Among Organizational and Distribution Forms and Capital and Asset Risk Structures in the Life Insurance Industry, Journal of Risk and Insurance, 70: 375-400.

Barclay, M. J., and C. W. Smith Jr., 1995, The Maturity Structure of Corporate Debt, Journal of Finance, 50: 609-631.

Berk, J. B., R. C. Green, and V. Naik, 1999, Optimal Investment, Growth Options, and Security Returns, Journal of Finance, 54: 1553-1607.

Berlin, M., and J. Loeys, 1988, Bond Covenants and Delegated Monitoring, Journal of Finance, 43; 397-412.

Black, K., Jr., and H. D. Skipper Jr., 2000. Life and Health Insurance (Upper Saddle River, NJ: Prentice Hall).

Brennan, M. J., N. Jegadeesh, and B. Swaminathan, 1993, Investment Analysis and the Adjustment of Stock Prices to Common Information, Review of Financial Studies, 6: 799-824. 
Brennan, M. J., and A. Subrahmanyam, 1995, Investment Analysis and Price Formation in Securities Markets, Journal of Financial Economics, 38: 361-381.

Brennan, M. J., and Tamarowski, C., 2000, Investor Relations, Liquidity and Stock Prices, Journal of Applied Corporate Finance, 12(4): 26-37.

Campbell, T., and Kracaw, W., 1980, Information Production, Market Signaling and the Theory of Intermediation, Journal of Finance, 35: 863-882.

Chamberlain, S., and S. Tennyson, 1998, Capital Shocks and Merger Activity in the Property-Liability Insurance Industry, Journal of Risk and Insurance, 65: 563-595.

Chan, K., W. Christie, and P. Schultz, 1995, Market Structure and the Intraday Pattern of Bid-Ask Spreads for NASDAQ Securities, Journal of Business, 68: 35-60.

Chung, K. H., T. H. McInish, R. A. Wood, and D. J. Wyhowski, 1995, Production of Information, Information Asymmetry and the Bid-Ask Spread: Empirical Evidence From Analysts' Forecasts, Journal of Banking and Finance, 19: 1025-1046.

Colquitt, L. L., R. E. Hoyt, and K. A. McCullough, 2006, The Impact of Asbestos and Environmental Reserves Increases on Shareholder Wealth, North American Actuarial Journal, 10: 17-31.

Conrad, J., and C. M. Niden, 1992, Order Flow, Trading Costs and Corporate Acquisition Announcements, Financial Management, 21: 22-31.

Copeland, T. C., and D. Galai, 1983, Information Effects of the Bid-Ask Spread, Journal of Finance, 38: 1457-1469.

Cox, L. A., and Y. Ge, 2004, Temporal Profitability and Pricing of Long-Term Care Insurance, Journal of Risk and Insurance, 71: 677-705.

Cox, L. A., and G. L. Griepentrog, 1988, The Pure-Play Cost of Equity for Insurance Divisions, Journal of Risk and Insurance, 55: 442-452.

Cummins, J. D., 1991, Statistical and Financial Models of Insurance Pricing and the Insurance Firm, Journal of Risk and Insurance, 58: 261-302.

Cummins, J. D., and J. Lamm-Tennant, 1994, Capital Structure and the Cost of Equity Capital in the Property-Liability Insurance Industry, Insurance: Mathematics and Economics, 15: 187-201.

Cummins, J. D., R. D. Phillips, and S. D. Smith, 2001, Derivatives and Corporate Risk Management: Participation and Volume Decisions in the Insurance Industry, Journal of Risk and Insurance, 68: 51-91.

Cummins, J. D., S. Tennyson, and M. A. Weiss, 1999, Consolidation and Efficiency in the U.S. Life Insurance Industry, Journal of Banking and Finance, 23: 325-357.

Demsetz, H., 1968, The Cost of Transaction, Quarterly Journal of Economics, 82: 33-53.

Diamond, D, 1984, Financial Intermediation and Delegated Monitoring, Review of Economic Studies, 51: 393-414.

Diamond, D. W., 1989, Reputation Acquisition in Debt Markets, Journal of Political Economy, 97: 828-862.

Diamond, D. W., 1991, Monitoring and Reputation: The Choice Between Bank Loans and Directly Placed Debt, Journal of Political Economy, 99: 689-721.

Dionne, G., and N. Doherty, 1992, Adverse Selection in Insurance Markets: A Selective Survey, in: G. Dionne, ed., Contributions to Insurance Economics (Boston: Kluwer Academic), pp. 97-140. 
Easley D., and M. O'Hara, 1992, Time and the Process of Security Price Adjustment, Journal of Finance, 47: 577-605.

Fenn, G., and R. Cole, 1994, Announcements of Asset-Quality Problems and Contagion Effects in the Life Insurance Industry, Journal of Financial Economics, 35: 181-198.

Flannery, M., S. Kwan, and M. Nimalendran, 2004, Market Evidence on the Opaqueness of Banking Firm's Assets, Journal of Financial Economics, 71: 419-460.

Garven, J. R., and S. W. Pottier, 1995, Incentive Contracting and the Role of Participation Rights in Stock Insurers, Journal of Risk and Insurance, 62(2): 253-270.

George, T. J., G. Kaul, and M. Nimalendran, 1991, Estimation of the Bid-Ask Spread and Its Components: A New Approach, Review of Financial Studies, 4: 623-656.

Glosten, L. R., and P. R. Milgrom, 1985, Bid, Ask and Transaction Prices in a Specialist Market with Heterogeneously Informed Traders, Journal of Financial Economics, 14: 71-100.

Glosten, L. R., and L. E. Harris, 1988, Estimating the Components of the Bid/Ask Spread, Journal of Financial Economics, 21: 123-142.

Greene, W. H., 1995, LIMDEP Version 7.0 User's Manual (Bellport, NY: Econometric Software).

Grosen, A., and P. L. Jorgensen, 2002, Life Insurance Liabilities at Market Value: An Analysis of Insolvency Risk, Bonus Policy, and Regulatory Intervention Rules in a Barrier Option Framework, Journal of Risk and Insurance, 69(1): 63-91.

Harris, L., and A. Raviv, 1993, Differences of Opinion Make a Horse Race, Review of Financial Studies, 473-506.

Hendel, I., and A. Lizzeri, 2003, Role of Commitment in Dynamic Contracts: Evidence From Life Insurance, Quarterly Journal of Economics, 118: 299-327.

Hentschel, L., and C. W. Smith Jr., 1997, Risks in Derivatives Markets: Implications for the Insurance Industry, Journal of Risk and Insurance, 64(2): 323-345.

Ho, T., and H. Stoll, 1981, Optimal Dealer Pricing Under Transactions and Return Uncertainty, Journal of Financial Economics, 9: 47-73

Huang, R. D., and H. R. Stoll, 1997, The Components of the Bid-Ask Spread: A General Approach, Review of Financial Studies, 10: 995-1034.

Irvine, P. J., 2003, The Incremental Impact of Analyst Initiation of Coverage, Journal of Corporate Finance, 9: 431-451.

James, C., 1987, Some Evidence of the Uniqueness of Bank Loans, Journal of Financial Economics, 14: 217-235.

Jensen, M. C., 1986, Agency Costs of Free Cash Flow, Corporate Finance, and Takeovers, AEA Papers and Proceedings, 76: 323-329.

Jensen, M. C., and W. H. Meckling, 1976, Theory of the Firm: Managerial Behavior, Agency Costs and Ownership Structure, Journal of Financial Economics, 3: 305-360.

Karpoff, J., 1986, A Theory of Trading Volume, Journal of Finance, 41: 1060-1088.

Karpoff, J., 1987, The Relation Between Price Changes and Trading Volume, Journal of Financial and Quantitative Analysis, 22: 109-126

Kim, O., and R. E. Verrecchia, 1994, Market Liquidity and Volume Around Earnings Announcements, Journal of Accounting and Economics, 17: 41-67. 
Krinsky, I., and J. Lee, 1996, Earnings Announcements and the Components of the Bid-Ask Spread, Journal of Finance, 51: 1523-1535.

Kyle, A. S., 1985, Continuous Auctions and Insider Trading, Econometrica, 53: 13151336.

Lin, J., G. Sanger, and G. G. Booth, 1995, Trade Size and Components of the Bid-Ask Spread, Review of Financial Studies, 8: 1153-1183.

Lummer, S. L., and J. J. McConnell, 1989, Further Evidence on the Bank Lending Process and the Capital Market Response to Bank Loan Agreements, Journal of Financial Economics, 25: 99-122.

Madhavan, A., M. Richardson, and M. Roomans, 1997, Why Do Security Prices Change? A Transaction-Level Analysis of NYSE Stocks, Review of Financial Studies, 10: 1035-1064.

Madhavan A., and S. Smidt, 1991, A Bayesian Model of Intraday Specialist Pricing, Journal of Financial Economics, 30: 99-134.

McInish, T., and R. Wood, 1992, An Analysis of Intraday Patterns in Bid/Ask Spreads for NYSE Stocks, Journal of Finance, 47: 99-117.

Merton, R., 1987, A Simple Model of Capital Market Equilibrium With Incomplete Information, Journal of Finance, 42: 483-510.

Morgan, D. P., 2002, Rating Banks: Risk and Uncertainty in an Opaque Industry, American Economic Review, 92(4): 874-888.

Myers, S., and P. Majluf, 1984, Corporate Financing and Investment Decision When Firms Have Information That Investors Do Not Have, Journal of Financial Economics, 13: $187-221$.

National Association of Insurance Commissioners, 2007, Risk-Based Capital (RBC) Model Act, 2007 (Kansas City, MO: National Association of Insurance Commissioners).

Phillips, R., J. D. Cummins, and F. Allen, 1998, Financial Pricing of Insurance in the Multiple Line Insurance Company, Journal of Risk and Insurance, 65: 597-636.

Polonchek, J., and R. Miller, 1996, The Valuation Effects of Insurance Company Securities Issuances, in: M. Hirschey and M. W. Marr, eds., Advances in Financial Economics, Vol. 2 (Amsterdam: Elsevier), pp. 187-204.

Polonchek, J., and R. K. Miller, 1999, Contagion Effects in the Insurance Industry, Journal of Risk and Insurance, 66: 459-475.

Ross, S., 1989, Institutional Markets, Financial Marketing, and Financial Innovation, Journal of Finance, 44: 541-556.

Santomero, A. M., and D. F. Babbel, 1997, Financial Risk Management by Insurers: An Analysis of the Process, Journal of Risk and Insurance, 64(2): 231-270.

Schwartz, R., 1988, Equity Markets (New York: Harper \& Row).

Slovin, M., M. Sushka, and J. Polonchek, 1992, Informational Externalities of Seasoned Equity Issues: Differences Between Banks and Industrial Firms, Journal of Financial Economics, 31: 411-425.

Stoll, H., 1978, The Pricing of Security Dealer Services: An Empirical Study of NASDAQ Stocks, Journal of Finance, 33: 1153-1172. 
Stoll, H., 1989, Inferring Components of the Bid-Ask Spread: Theory and Empirical Tests, Journal of Finance, 44: 115-134.

Stoll, H., 2000, Friction, Journal of Finance, 55: 1479-1514.

Stulz, R., 1990, Managerial Discretion and Optimal Financing Policies, Journal of Financial Economics, 26: 3-27.

Tinic, S., and R. West, 1972, Competition and the Pricing of Dealer Service in the Over-the-Counter Stock Market, Journal of Financial and Quantitative Analysis, 7: 1707-1727.

United States General Accounting Office, 1999, Medical Malpractice-Effects of Varying Laws in the District of Columbia, Maryland, and Virginia, GAO/HEHS-00-5.

United States General Accounting Office, 2002, Terrorism Insurance-Implementation of the Terrorism Risk Insurance Act of 2002, GAO-04-307.

Van Ness, B., R. Van Ness, and R. Warr, 2001, How Well Do Adverse Selection Components Measure Adverse Selection?, Financial Management, 5-30.

Van Ness, B., R. Van Ness, and R. Warr, 2005, The Impact of Market Maker Concentration on Adverse Selection for NASDAQ Stocks, Journal of Financial Research, 28(3): 461-485.

Williamson, O. E., 1985, The Economic Institution of Capitalism (New York: Free Press/Macmillan). 